\title{
Monitoring Pyricularia sp. airborne inoculum in Passo Fundo, Rio Grande do Sul, Brazil
}

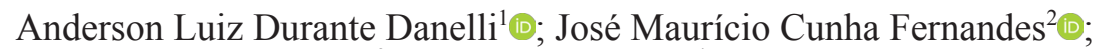 \\ João Leodato Nunes Maciel $^{3} ₫$; Cristina Boaretto ${ }^{4} ;$; Carlos Alberto Forcelini ${ }^{5} \bullet$
}

\begin{abstract}
${ }^{1}$ Pós-Graduação em Agronomia-PPG Agro-Universidade de Passo Fundo (UPF), BR-285, CEP: 99052-900, Passo Fundo, RS, Brasil, Bolsista Capes/Prosup/UPF; ${ }^{2}$ Pesquisador, Embrapa Trigo, BR-285, CEP: 99001-970, Passo Fundo, RS, Brasil, Professor, Faculdade de Agronomia e Medicina Veterinária, UPF, BR-285, CEP: 99052-900, Passo Fundo, RS, Brasil; ${ }^{3}$ Pesquisador, Embrapa Trigo, BR-285, CEP: 99001-970, Passo Fundo, RS, Brasil; ${ }^{4}$ Pós-Graduação em Agronomia-PPGAgro-Universidade de Passo Fundo (UPF), BR-285, CEP: 99052-900, Passo Fundo, RS, Brasil; ${ }^{5}$ Professor, Faculdade de Agronomia e Medicina Veterinária, UPF, BR-285, CEP: 99052-900, Passo Fundo, RS, Brasil.

Corresponding author: Anderson Luiz Durante Danelli (prof_andersondanelli@uniguacu.edu.br)
\end{abstract}

Data de chegada: 05/04/2017. Aceito para publicação em: 30/01/2019

\section{ABSTRACT}

Danelli, A.L.D.; Fernandes, J.M.C.; Maciel, J.L.N.; Boaretto, C.; Forcelini, C. A. Monitoring Pyricularia sp. airborne inoculum in Passo Fundo, Rio Grande do Sul - Brazil. Summa Phytopathologica, v.45, n.4, p.361-367, 2019.

The fungus Pyricularia sp., the causal agent of wheat blast, produces light, dry and hyaline conidia that can be removed from sporulating lesions by the wind and transported over long distances. Experiments were performed with the aim of (a) determining the relationship between the climate variables and the quantity of conidia of Pyricularia sp., and (b) obtaining technical data that can be used in the elaboration of blast forecasting models. From February $2^{\text {nd }}$, 2013 to June $7^{\text {th }}, 2014$, the number of Pyricularia sp. conidia in the air was monitored by using a spore trap and glass slides smeared with vaseline. Several climate variables were hourly recorded during the spore capturing period. The data were explored based on classification trees and relationships between the weather-based predictors and the number of trapped conidia day ${ }^{-1}$. The strongest predictors were mean relative humidity, daily mean temperature, precipitation lower than $5 \mathrm{~mm} \mathrm{day}^{-1}$, and number of hours when temperature was between 15 and $35^{\circ} \mathrm{C}$ and relative humidity $>93 \%$.

Keywords: Triticum aestivum, Oryza sativa, weather factors, forecasting models.

\section{RESUMO}

Danelli, A.L.D.; Fernandes, J.M.C.; Maciel, J.L.N.; Boaretto, C.; Forcelini, C. A. Monitoramento de inóculo no ar de Pyricularia sp. em Passo Fundo Rio Grande do Sul - Brasil. Summa Phytopathologica, v.45, n.4, p.361-367, 2019.

O fungo Pyricularia sp. agente causal da brusone do trigo, produz conídios hialinos, secos e leves que podem ser removidos das lesões esporulativas pelo vento, e transportados a longas distâncias. Foram conduzidos experimentos com o objetivo de determinar (a) a relação entre variáveis meteorológicas e a quantidade de conídios de Pyricularia sp. no ar e (b) e obter dados técnicos que possam ser usados na elaboração de modelos de previsão de brusone. No período entre 2 de fevereiro de 2013 e 7 de junho de 2014, foi monitorado o número de conídios de Pyricularia sp. no ar, com o auxílio de armadilha coletora de esporos e lâminas de vidro untadas com vaselina. Neste período, foram registradas de hora em hora algumas variáveis climáticas, presentes durante a captura dos esporos. Os dados foram explorados através do uso de árvores de classificação, e relações entre preditores à base de variáveis climáticas e número de conídios capturados $\operatorname{dia}^{-1}$. Os preditores mais fortes foram umidade relativa do ar média, temperatura média diária, precipitação menor que $5 \mathrm{~mm} \mathrm{dia}^{-1}$ e números de horas em que a temperatura estava entre 15 e $35^{\circ} \mathrm{C}$ e umidade relativa do ar $>93 \%$.

Palavras-chave: Triticum aestivum, Oryza sativa, fatores climáticos, modelos preditivos.

The fungus Pyricularia oryzae (Cavara) presents a wide range of hosts and can be found in several plants, particularly species of the Poaceae family, such as barley (Hordeum vulgare L.) (7), perennial ryegrass (Lolium perenne L.) (10), elephant grass (Pennisetum purpureum Schumach.), and millet (P. glaucum (L.) R. Br.) (30). Although $P$. oryzae infects several plant species, rice is the most known crop affected by this fungus, producing the famous disease known as rice blast, first reported in the $15^{\text {th }}$ century (19). In the mid-1980s, blast was first reported in wheat in Brazil (12). In 2016, wheat blast was found outside South America, more precisely in Bangladesh, Asia (8).

Occurrence of wheat blast is not homogeneous among the different Brazilian regions where wheat is cultivated. In the Brazilian state of Rio Grande do Sul (RS), where the county of Passo Fundo is located, the incidence of this disease is very low and does not cause damages of economic importance. A hypothesis for such low occurrence of wheat blast in RS is the absence of wheat fields in periods when there is a combination of high concentration of propagules of $P$. oryzae and good conditions for the development of that disease, i.e., temperature between 24 and $28^{\circ} \mathrm{C}$ and Relative Humidity (RH) $>90 \%(19,1)$.

Pyricularia oryzae produces a hyaline conidium, with two or three septa, which is attached to the conidiophore by a cell that splits in two when the conidiophore is mature, releasing it (23). According to Castejón-Muñoz (2), an increase of $1{ }^{\circ} \mathrm{C}$, during tillering rice growth, increases the disease severity. On the other hand, conidia production is benefited by $\mathrm{RH} \geq 90 \%$ and temperature around $28^{\circ} \mathrm{C}(1)$. Conidia are dry, light, and may be removed by the wind from sporulating lesions and transported over long distances. The release and transportation of this type of propagules occur at nighttime, peaking between $24 \mathrm{~h}$ and 
$6 \mathrm{~h}$, when RH is high (100\%) and temperatures are around $22{ }^{\circ} \mathrm{C}(6)$. Airborne dissemination is considered the major means of transportation, as distance may be up to 1,000 meters from an infected field (29). In this regard, studies developed in rice have shown that the concentration of airborne conidia is related to weather conditions, which indicates a risk factor for infections and development of epidemics $(21,22)$.

Although Silva \& Prabhu (28) have already conducted studies in Brazil about occurrence of $P$. oryzae spores in the air, knowledge about this theme is still very initial in the country. The aerial inoculum dynamics of this pathogen should be considered for rice and/or wheat blast management strategy in the fields. An efficient methodology to monitor aerial $P$. oryzae propagules is the use of spore collection traps. Currently, two types of traps have been used to collect and quantify spores of plant pathogens: automatic and wind vane (14, 24, 20, 25). Correia \& Costa (5) mentioned that the efficiency of automatic traps is higher. However, the same authors emphasized that the wind vane type has full conditions to allow adequate quantification of fungal spores present in the air.

The present study aimed to (a) determine the relationship between climate variables and airborne conidia of Pyricularia sp. and (b) obtain technical data that can be used in the elaboration of blast forecasting models.

\section{MATERIAL AND METHODS}

The activities concerning the experiments listed below were performed in the facilities of Embrapa Trigo (Embrapa Wheat), in Passo Fundo, Rio Grande do Sul, Brazil (28 13'37.22” S, 52²4’23.09” W, altitude $684 \mathrm{~m}$ ).

Pyricularia sp. conidia were monitored from February $2^{\text {nd }}, 2013$, to June $7^{\text {th }}, 2014$. To detect the presence of Pyricularia sp. propagules in the air, a wind vane type of trap was used (24). The trap was built by using a white $30 \mathrm{~cm}$-long PVC pipe with internal diameter of $10 \mathrm{~cm}$. At the rear end, a rudder was fixed to allow the trap to be directed by the wind. The front side of the PVC pipe was cut at a $45^{\circ}$ angle and its tip was positioned upwards, providing better protection of the glass slide inside the trap against rainwater and sunlight (Figure 1A). The trap was fixed at $1.50 \mathrm{~m}$ above ground level. The collecting surface consisted of a glass slide $(7.5 \times 2.5 \mathrm{~cm})$ smeared with solid vaseline solution (Rioquímica) (Figure 1B). Glass slides were placed against the wind at a $45^{\circ}$ angle in relation to the inner PVC tube base and were replaced every 24 hours at $9 \mathrm{am}$. During conidia monitoring, climate variables, such as temperature, $\mathrm{RH}$, wind, solar radiation, dew-point temperature and rainfall, were recorded every hour with of a micro-meteorological station (Watch-Dog model 450) (Figure 1C). Pyricularia sp. conidia were identified and quantified by scan counts, from the $7.5 \times 2.5 \mathrm{~cm}$ glass slides with two $18 \times 18 \mathrm{~mm}$ coverslips, under a light microscope (Nikon Eclipse E 200), 40x objective lenses.

The hourly meteorological datasets and the daily counts of conidia of Pyricularia sp. were used to explore the relationship between daily number of collected conidia and climate variables. Some predictors were simple summaries, such as total rainfall per day; others summarized two target conditions met simultaneously, such as the number of hours with temperatures between $15^{\circ} \mathrm{C}$ and $35^{\circ} \mathrm{C}$ in a time window and $\mathrm{RH}>93 \%$, representing relatively warm temperatures combined with high RH.

The major weather-based predictors were selected by using the "tree method" classification, providing conditions to produce

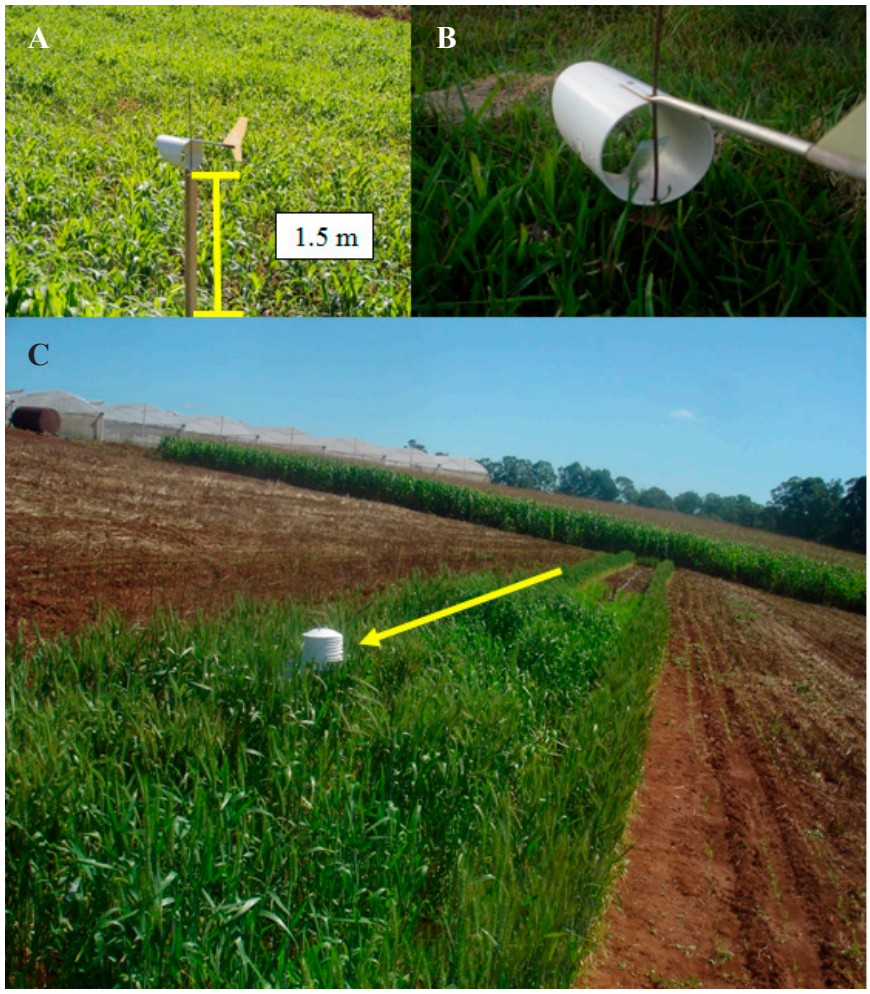

Figure 1. Spore trap was fixed at $1.50 \mathrm{~m}$ above ground level (A), trap containing a glass slide smeared with solid vaseline (B), and micrometeorological station (C). Passo Fundo, RS, Brazil, 2019.

forecasting models (11). One of the advantages of this type of test is the great number of variables that can be analyzed simultaneously, and the induction algorithm has the capability of indicating the most representative variable (16).

A zero-inflated negative binomial regression was used to model the number of conidia. The zero-inflated negative binomial regression test is indicated in the case of counting data with an excessive number of zeros, which can cause super dispersion and interfere in adjusting of the model (17). To evaluate the developed model, a ROC curve (Receiver Operating Characteristic) was adopted. This curve can be used to verify the model's capability of predicting or selecting models (18). The entire exploratory analysis of data was performed with $\mathrm{R}$ Statistical and Graph computer program.

\section{RESULTS AND DISCUSSION}

During the propagule quantification period, 240 Pyricularia sp. conidia were identified and the mean concentration over 492 collection days was 0.49 conidia day $^{-1}$. The highest number of Pyricularia sp. propagules collected in only one day was recorded on March $10^{\text {th }}$, 2013, when 48 conidia were counted. Weather conditions recorded throughout the experiment allowed to relate the quantified conidia to each climate variable (Figure 2). The plotting of Pyricularia sp. conidia against temperature indicated a higher concentration of propagules at temperatures between 15 and $25^{\circ} \mathrm{C}$, and trapped conidia peaked at temperatures close to $20^{\circ} \mathrm{C}$ (Figure 2A). Regarding accumulated rainfall $(\mathrm{mm})$ per day as an independent variable, the dispersion of 
conidia occurred between 0 and $80 \mathrm{~mm}$; however, accumulation of propagules was higher when rainfall was lower than $5 \mathrm{~mm}$ (Figure 2B). Relative humidity ranged from 40 to $100 \%$ during conidia capturing; bellow that $\mathrm{RH}$, no propagules were captured in the assessed glass slides, and the peak was between 80 and 90\% RH (Figure 2C). The concentration of propagules was highest during the first months of the year (Figure 2D).

A new variable was introduced with the obtained data; in this case, the accumulated number of hours when temperatures were between 15 and $35^{\circ} \mathrm{C}$ and $\mathrm{RH}>93 \%$. This variable was expressed as the acronym cb1. Weather-based predictors were selected through the "tree method" classification for the number of conidia (Figure 3). Based on this classification method to associate the weather variables with the number of captured propagules, there was a reduction in the number of favorable hours (represented by the acronym "cb1" on the tree). According to the analysis shown in Figure 3, under precipitation $\geq 1.2 \mathrm{~mm}$, an average of 1,552 conidia day ${ }^{-1}$ was found in a 67 -day period. The highest average number of captured conidia, 20,220 day ${ }^{-1}$, was recorded when relative humidity was higher than $85.8 \%$, which occurred in 9 days. When RH was inferior to $85.8 \%$, in 22 days, the average of propagules found in each of these days was 2,773 propagules day ${ }^{-1}$ (Figure 3).

The highest number of conidia was captured when precipitation was lower than $5 \mathrm{~mm}$ (Figures 4 and 5). Regarding the number of conidia trapped per day, there was an excess of days with zero counts which means that, in these days, there were no conidia in the assessed glass slides. This fact allowed the use of the zero-inflated negative binomial regression test to model the number of conidia. The used model enabled estimating the expected number of conidia trapped by different combinations of weather-based predictors (Figure 5). In this case, the model estimated a higher number of trapped conidia with rainfall lower than $5 \mathrm{~mm}$ and lower demand for number of favorability hours day ${ }^{-1}$, i.e., the number of hours when temperature was between 15 and $35^{\circ} \mathrm{C}$ and $\mathrm{RH}>93 \%$. When rainfall was higher than $5 \mathrm{~mm}$, the number of favorability hours day ${ }^{-1}$ was higher; therefore, the expected number of trapped conidia was lower.

A logistic regression model was used to verify the presence or absence of Pyricularia sp. conidia per day, using data collected from February $2^{\text {nd }}, 2013$, to June $7^{\text {th }}, 2014$. The weather-based predictors were total rainfall per day and number of hours when temperature was between 15 and $35^{\circ} \mathrm{C}$ and $\mathrm{RH}>93 \%$. The binary transformation was set to 1 when the number of conidia was higher than 3, and zero otherwise. The area under the curve (AUC), which reflects the accuracy rate of the model, was $73 \%$ with confidence interval of $62.7-81.4 \%$ (Figure 6 ).

The quantity of Pyricularia sp. conidia in the air over a relatively long time (over a year) represented very well the dynamics of this type of propagules in the air in Passo Fundo, RS, confirming that the type of used trap (wind vane) was efficient to sample and capture spores of the studied pathogen. This was evidenced by the relationship between the variables considered in this study and the amount of Pyricularia sp. conidia in the air, which validated very feasible forecasting models
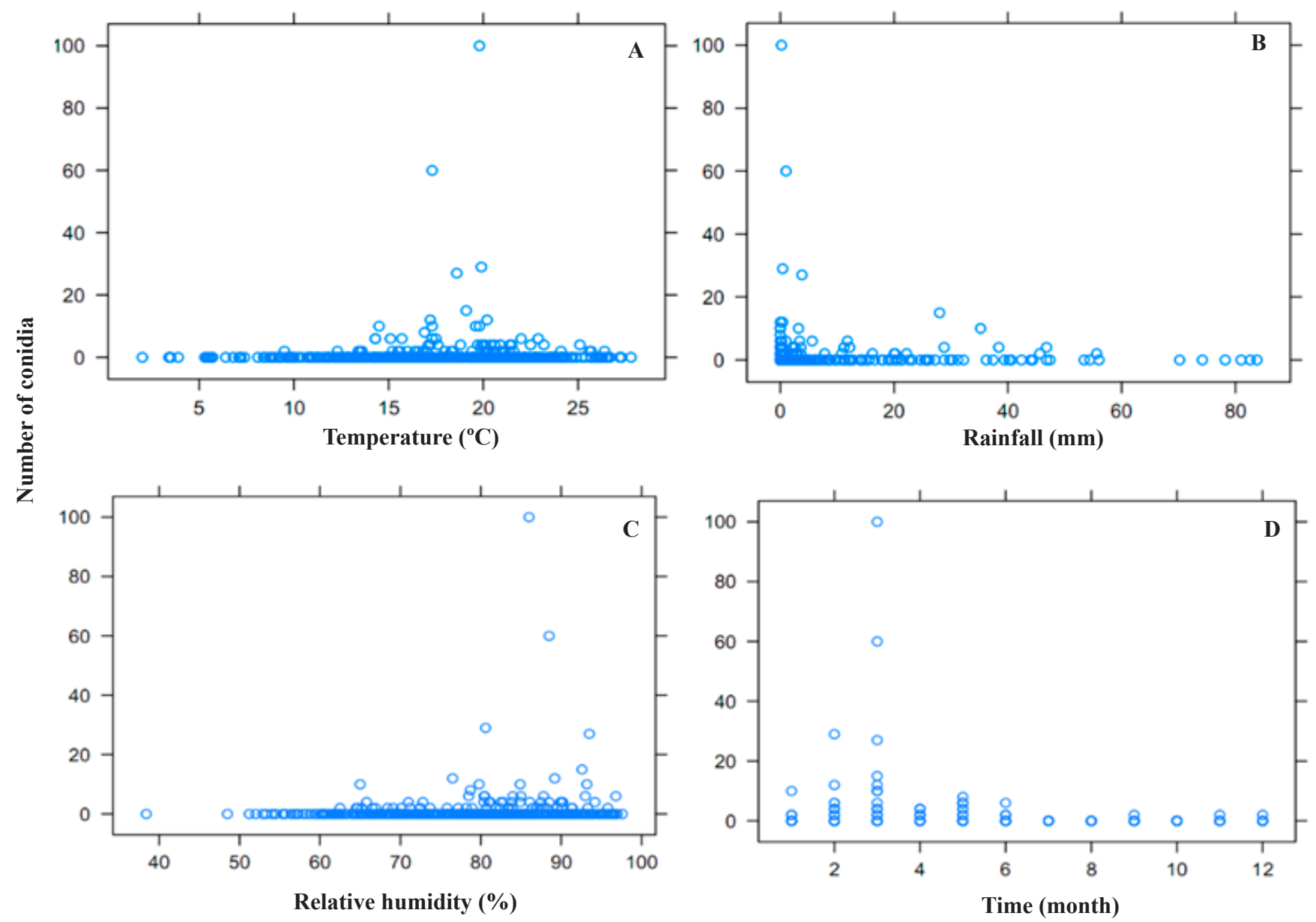

Figure 2. Daily records of Pyricularia sp. conidia dispersion related to mean temperature (A), total rainfall (B), mean relative humidity (C), and month of the year (D), from February $2^{\text {nd }}, 2013$, to June $7^{\text {th }}, 2014$, in Passo Fundo, RS, Brazil, 2019. 


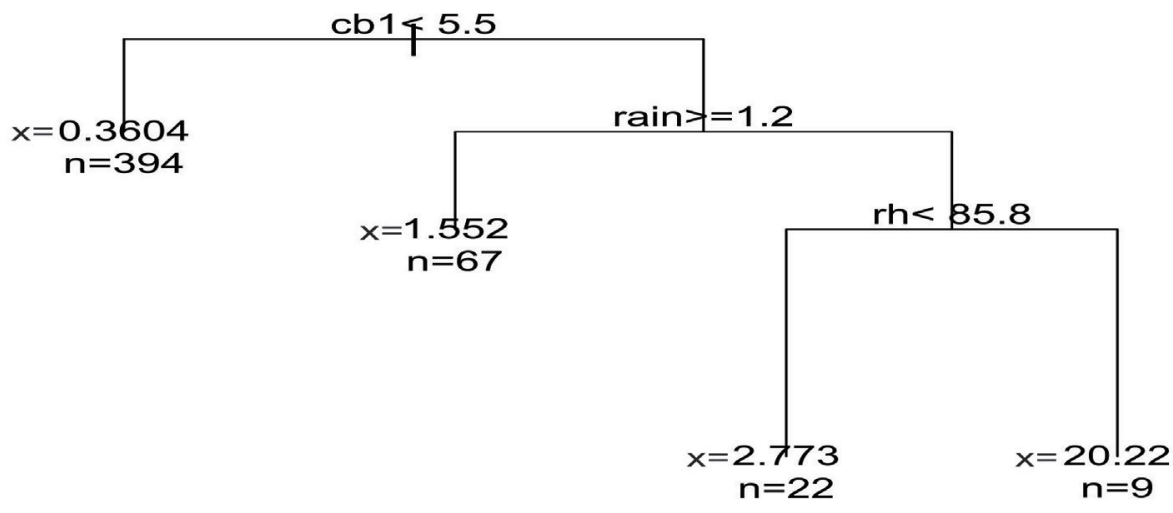

Figure 3. Classification tree for the prevalence of conidia numbers. "cbl" is the number of hours when temperature was between 15 and $35^{\circ} \mathrm{C}$ and relative humidity $>93 \%$; " $\mathrm{x}$ " is the conidia average found during the period and " $\mathrm{n}$ " is the period evaluated in days. Passo Fundo, RS, Brazil, 2019.

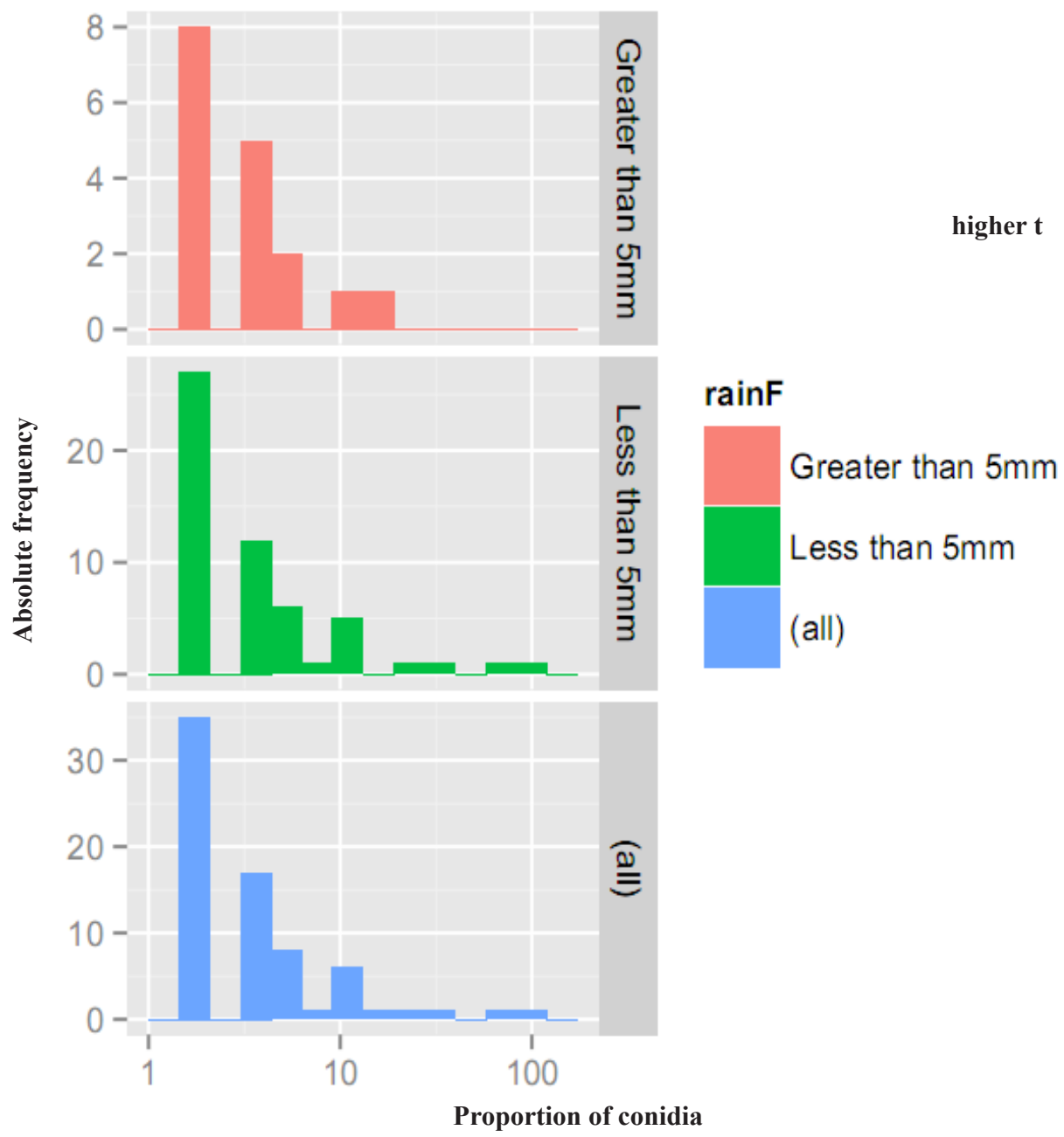

Figure 4. Rainfall and frequency of Pyricularia sp. conidia trapped per day, between February $2^{\text {nd }}, 2013$, and June $7^{\text {th }}$, 2014, in Passo Fundo, RS, Brazil, 2019.

for blast epidemics. These assertions and interpretations are supported by specific analyses, such as the "tree method" (Figure 3), and by the logistic regression model (Figure 6), which confirmed the relationship between the number of collected conidia dia $^{-1}$ and variables such as temperature, $\mathrm{RH}$, acronym "cb1", precipitation, months and days of the year. It is still important to highlight that the "tree method" has already validated models of epidemics for other wheat diseases such as wheat scab in the United States. This condition allowed finding predictors that show strong association with $\mathrm{RH}$, temperature and number of hours when temperature was between 9 and $30^{\circ} \mathrm{C}$ and $\mathrm{RH} \geq 90 \%$, considering that the AUC varied from $82 \%$ to $91 \%$ for the developed models (26). Shah et al. (27), aiming to identify windows of weather variables in 


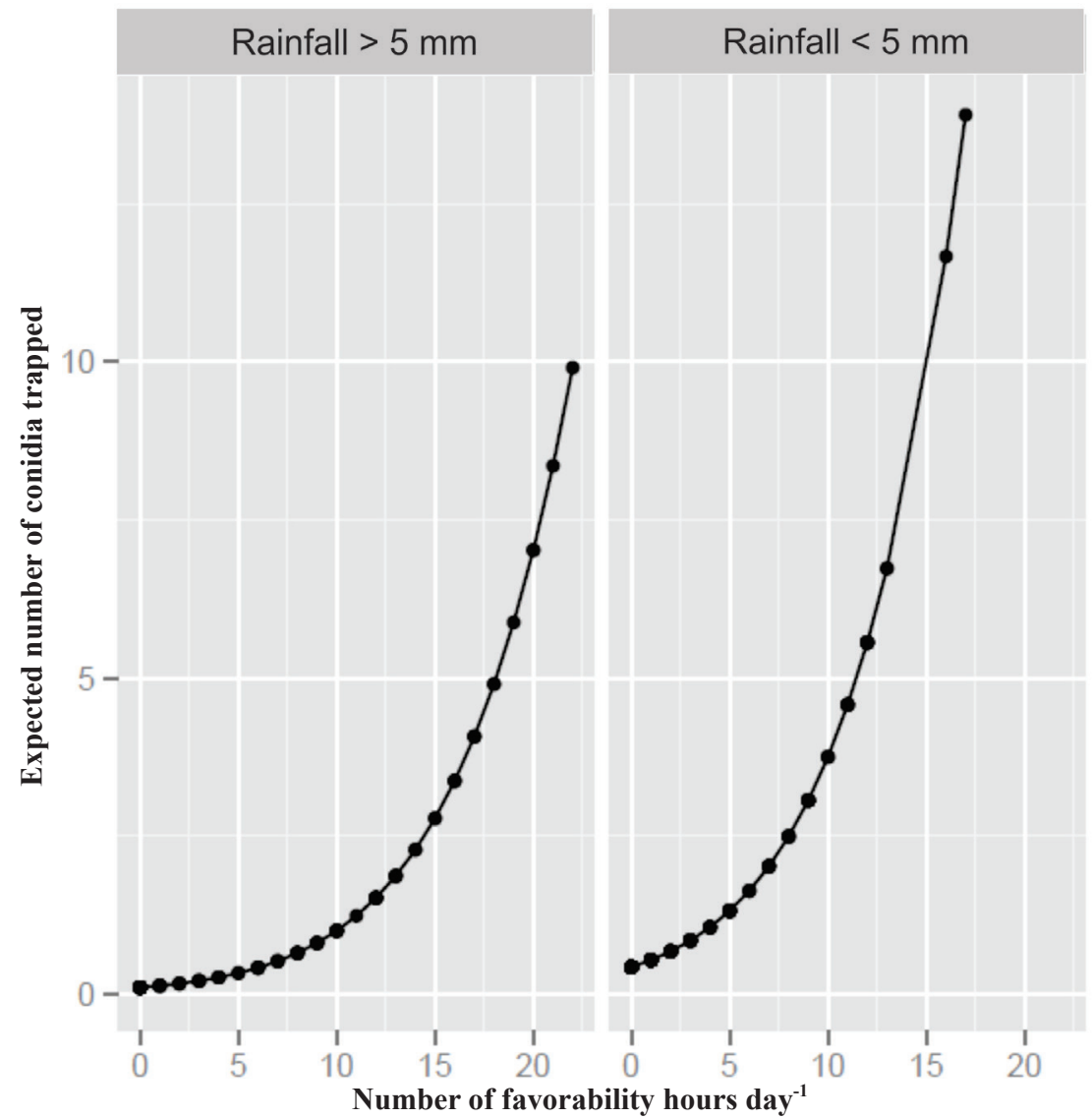

Figure 5. Zero-inflated negative binomial model, built with daily counts of Pyricularia sp. conidia trapped between February $2^{\text {nd }}$, 2013, and June $7^{\text {th }}, 2014$, in Passo Fundo, RS, Brazil. The weather-based predictors were total rainfall per day and number of hours when temperature was between 15 and $35{ }^{\circ} \mathrm{C}$ and relative humidity $>93 \%$. Passo Fundo, RS, Brazil, 2019.

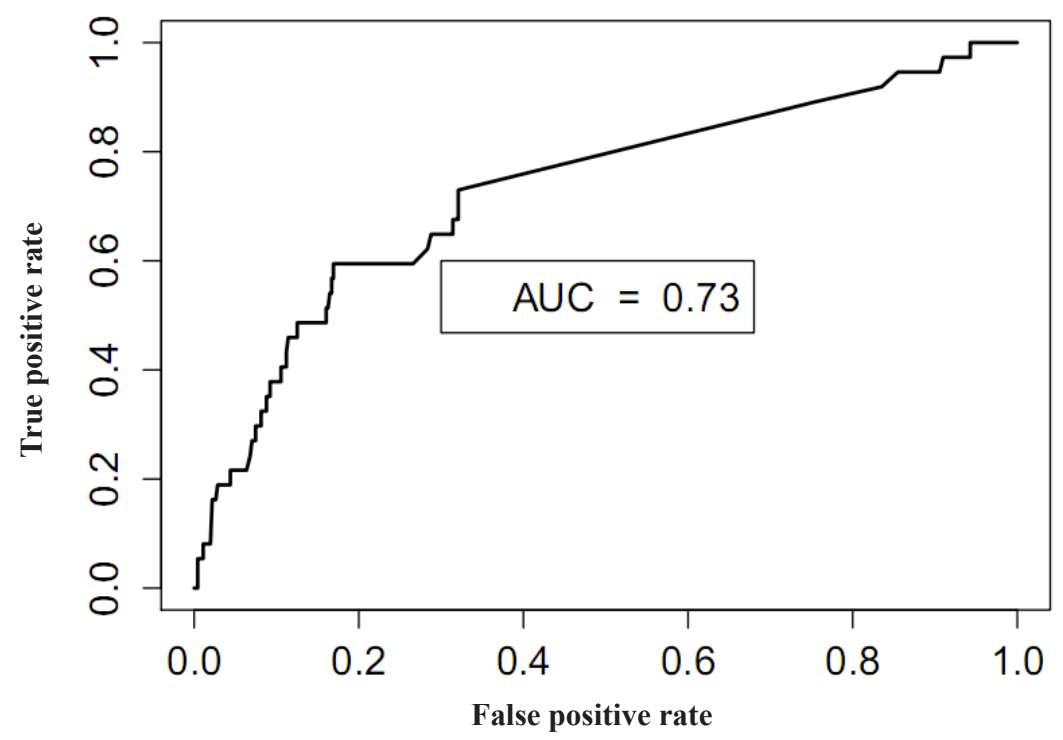

Figure 6. Receiver operating characteristic (ROC curve). The area under the curve (AUC) was 73\% (CI =62.7-81.4\%), Passo Fundo, RS, Brazil, 2019. 
pre- and post-anthesis to predict wheat scab epidemics, developed 15 weather-based predictors, of which 14 were associated with RH and only one with rainfall. Manstretta \& Rossi (13) evaluated the effect of weather-based predictors on the release and peak of ascospores of Gibberella zeae in northern Italy between 2012 and 2014, using AUC analysis, and reported that the vapor pressure deficit was the best weather-based predictor with $79 \%$ for release and $84 \%$ for ascospore peak. In Brazil, Meira et al. (16), based on the "tree method", used variables such as mean temperatures during leaf wetness, pending load of fruit and relative humidity to develop a model to predict the emergence of coffee rust epidemics caused by Hemileia vastatrix. Using the "tree method" to identify the influence of meteorological variables on the occurrence of epidemics of Asian soybean rust in commercial crops, Megeto et al. (15) have also developed a forecasting model with $78 \%$ accuracy rate.

In relation to the decrease in the number of conidia found when rainfall was higher than $5 \mathrm{~mm}$, Kim (9) has already reported that rainwater above $3.5 \mathrm{~mm} /$ day can reduce the number of $P$. oryzae conidia present in plant lesions. This is due to the force of rainfall on conidiophores, which end up releasing conidia and reducing the amount of inoculum, thus affecting dissemination. Silva \& Prabhu (28) also verified the existence of an inverse relationship between rainfall and trapped $P$. oryzae conidia.

It is important to emphasize that the concentration of Pyricularia sp. conidia in the air was higher during the first three months of the year (Figure 2B). In those periods, occurrence of several days under favorable conditions of temperature, humidity and precipitation to the development of blast was also recorded. Such data allowed estimating that, in Passo Fundo, specific moments of the year require more concern about occurrence of blast diseases. This is one of the main results obtained in the present study.

Nevertheless, two crucial variables must also be included in any analysis of the study. The first one is the factor "presence or absence" of crops in the field in the period when there is combination of favorable climate for the disease and high concentration of pathogen spores in the air. This situation is especially related to the data obtained during the first three months of the year, when climate conditions were favorable to the disease and the concentration of Pyricularia sp. conidia in the air was higher. However, that period is not a regular season for wheat crop in the region. In addition, in Passo Fundo, which is located in the north of Rio Grande do Sul, there is no cultivation of rice, differently from the south of this Brazilian state, where the major area occupied by this crop in Brazil is located. The second variable is the site where the spores were collected. The obtained data may assist in developing forecasting models for blast diseases in other Brazilian regions where damages caused by blast diseases in the fields are more significant. However, the best strategy would be to monitor the flow of Pyricularia $\mathrm{sp}$. conidia in the air in more places in the country, especially where there is intention of including the pathogen's airborne inoculum in the management of blast diseases.

Obviously, it would be desirable that the obtained data also included the host plant species of each spore found on the glass slides. However, considering the complexity of the genus Pyricularia (or Magnaporthe) in relation to its taxonomic variability, associated with the current "state of the art" on the subject, such a highly detailed monitoring is a great challenge, and technical and taxonomical aspects have not yet been overcome. This includes, for example, the recent proposal of the species Pyricularia graminis-tritici as the second causal agent of wheat blast (3). The molecular markers developed by Chada \& Gopalakrishna (4) and Villari et al. (31) constitute tools that could be tested to detect and differentiate the causal agents of rice and wheat blast found in spore traps such as those used in the present study. However, even if such markers were used, a preliminary study relating the detection and the diversity of the genus Pyricularia present in Brazil would be necessary.

The airborne flow of propagules of Pyricularia sp. in Passo Fundo, Rio Grande do Sul, is associated with weather variables.

The data obtained in the present study can be useful in the elaboration of forecasting models for blast epidemics.

\section{ACKNOWLEDGMENTS}

We would like to thank "Coordenação de Aperfeiçoamento de Pessoal de Nível Superior" (CAPES), "Programa de Suporte à Pós-Graduação de Instituições de Ensino Particulares" (PROSUP), "Universidade de Passo Fundo" (UPF), and "Embrapa Trigo", for the scholarships.

\section{REFERENCES}

1. Alves, K. J. P.; Fernandes, J. M. C. Influência da temperatura e da umidade relativa do ar na esporulação de Magnaporthe grisea em trigo. Fitopatologia Brasileira, Brasília, v. 31, n. 06, p. 579-584, 2006.

2. Castejón-Muñoz, M. The effect of temperature and relative humidity on the airborne concentration of Pyricularia oryzae spores and the development of rice blast in southern Spain. Spanish Journal of Agricultural Research, Madrid, v. 6, n. 01, p.61-69, 2008.

3. Castroagudin, V. L.; Moreira, S. I.; Pereira, D. A. S.; Moreira, S. S.; Brunner, P. C.; Maciel, J. L. N.; Crous, P.; Mcdonald, B. A.; Alves, E.; Ceresini, P. C. Pyricularia graminis-tritici, a new Pyricularia species causing wheat blast. Persoonia, Leiden, v. 37, n. 1, p. 199-216, 2016.

4. Chdha, S.; Gopalakrishna, T. Detection of Magnaporthe grisea in infested rice seed using polymerase chain reaction. Journal of Applied Microbiology, Oxford, v. 100, n. 5, p. 1147-1153, 2006.

5. Correia, M. S.; Costa, J. L. S. Dispersão anemófila do fungo Lasiodiplodia theobromae em plantações de coqueiro. Fitopatologia Brasileira, Brasília, v. 30, n. 02, p. 150-154, 2005.

6. Espinoza, I. G.; Shohara, K. Investigación relativa a la ocurrencia de Piricularia en trigo. Santa Cruz: Centro Tecnológico Agropecuário en Bolívia, Boletim Técnico 2. 2003.

7. Gutiérrez, A. S.; Cúndom, M. A. Pyricularia oryzae en cultivos de cebada en Corrientes (Argentina). Summa Phytopathologica, Botucatu, v. 41, n. 04, p. 318-320, 2015.

8. Islam, M. T.; Croll, D.; Gladieux, P.; Soanes, D. M.; Persoons, A.; Bhattat charjee, P.; Hossain, S.; Gupta, D. R.; Rahman, M. M.; Mahboob, M. G.; Cook, N.; Salam, M. U.; Sancho, V. B.; Maciel, J. L. N.; Nhani Júnior, A.; Castroagudín, V. L.; Reges, J. T. A.; Ceresini, P. C.; Ravel, S.; Kellner, R.; Fournier, E.; Tharreau, D.; Lebrun, M. H.; McDonald, B. A.; Stitt, T.; Swan, D.; Talbot, N. J.; Saunders, D. G. O.; Win, J.; Kamoun, S. Emergence of wheat blast in Bangladesh was caused by a south American lineage of Magnaporthe oryzae. Emergence of wheat blast in Bangladesh was caused by a South American lineage of Magnaporthe oryzae. BMC Biology, London, v. 14, n. 84, p. 1-11, 2016.

9. Kim, C. K. Blast management in high input, high potential temperature rice ecosystem. In: Zeigler, R. S.; Leong, S. A.; Teng, P. S. (Eds.) Rice blast disease. Wallingford, Reino Unido. CAB International. pp. 451-464. 1994.

10. Landschoot, P. J.; Hoyland, B. F. Gray leaf spot of perennial ryegrass turf in Pennsylvania. Plant Disease, St. Paul, v. 76, n. 12, p. 1280-1282, 1992.

11. Loh, W.-Y. Classification and regression trees. Wiley Interdisciplinary Reviews: Data Mining and Knowledge Discovery, v. 1, n. 01, p. 14-23, 2011.

12. Maciel, J. L. N.; Ceresini, P. C.; Castroagudin, V. L.; Zala, M.; Kema, G. H. J.; McDonald, B. Population structure and pathotype diversity of the wheat blast pathogen Pyricularia oryzae 25 years after its emergence in Brazil. Phytopathology, St. Paul, v. 104, n. 01, p. 95-107, 2014. 
13. Manstretta, V.; Rossi, Vittorio. Effects of weather variables on ascospore discharge from Fusarium graminearum perithecia. PLoS One, San Francisco, v. 10, n. 9, p. 1-20, 2015.

14. Marcuzzo, L. L.; Duffeck, M. R. Flutuação populacional de esporângios de Peronospora destructor no ar e sua relação com severidade do míldio da cebola. Summa Phytopathologica, Botucatu, v. 41, n. 01, p. 68-70, 2015.

15. Megeto, G. A. S.; Oliveira, S. R. De M.; Del Ponte, E. M.; Meira, C. A. A. Árvore de decisão para classificação de ocorrências de ferrugem asiática em lavouras comerciais com base em variáveis meteorológicas. Engenharia Agrícola, Jaboticabal, v. 34, n. 3, p. 590-599, 2014.

16. Meira, C. A. A.; Rodrigues, L. H. A.; Moraes, S. A. Análise da epidemia da ferrugem do cafeeiro com árvore de decisão. Tropical Plant Pathology, Brasília, v. 33, n. 02, p. 114- 124, 2008.

17. Nagamine, C. M. L. Modelos para dados de contagem: um estudo sobre o número de ovos do número de ovos do mosquito Aedes Aegypti/2007. 72 f. (Dissertação de mestrado) Mestrado em Estatística - Universidade Federal de São Carlos, São Carlos, SP.

18. Girolamo Neto, C. di G.; Rodrigues, L. H. A.; Meira, C. A. A.; Modelos de predição da ferrugem do cafeeiro (Hemileia vastatrix Berkeley \& Broome) por técnicas de mineração de dados. Coffee Science, Lavras, v. 9, n. 3, p. 408-418, 2014.

19. Ou, S. H. Blast. In: OU, S. H. (Ed.) Rice diseases. 2. ed. Wallingford, UK. CAB International, 1985. p. 109-201.

20. Paulitz, T. C. Diurnal release of ascospores by Gibberella zeae in inoculated wheat plots. Plant Disease, St. Paul, v. 80, n. 6, p. 674-678, 1996.

21. Picco, A. M.; Lorenzi, E.; Rodino, D.; Rodolfi, M.; Tabacchi, M.; Biloni, M. Airspores detection of Pyricularia grisea (Cooke) Sacc. and Bipolaris spp.: a three years monitoring in different rice fields in Northern Italy. In: Conference challenges and opportunities for sustainable rice-based production systems, 15., 2004, Torino. Proceedings... Roma: Ferrero and Vidotto, 2004. p. 161- 167.

22. Picco, A. M.; Rodolfi, M. Pyricularia grisea and Bipolaris oryzae: a preliminary study on the occurrence of airborne spores in a rice field. Aerobiologia, Bologna, v. 18, n. 02, p. 163-167, 2002.
23. Purchio, A. F.; Muchovej, J. J. O gênero Pyricularia e seus teleomorfos. In: Luz, W. C.; Fernandes, J. M.; Prestes, A. M.; Picinini, E. C. (Eds.) Revisão Anual de Patologia de Plantas. Passo Fundo: Berthier, 1994. p. 175-208.

24. Reis, E. M.; Santos, H. P. dos População de Helminthosporium sativum no ar através de uma armadilha tipo cata-vento. Fitopatologia Brasileira, Brasília, v. 10, n. 03 p. 515-519, 1985.

25. Rossi, V.; Languasco, L.; Pattori, E.; Giousue, S. Dynamics of airborne Fusarium macroconidia in wheat fields naturally affected by head blight. Journal of Plant Pathology, Pisa, v. 84, n. 1, p. 53-64, 2002.

26. Shah, D. A.; De Wolf, E. D.; Paul, P. A.; Madden, L. V. Predicting Fusarium head blight epidemics with boosted regression trees. Phytopathology, St. Paul, v. 104, n. 07, p. 702-714, 2014.

27. Shah, D. A.; Molineros, J. E.; Paul, P. A.; Willyerd, K. T.; Madden, L. V.; De Wolf, E. D. Predicting Fusarium head blight epidemics with weather-driven pre- and post-anthesis logistic regression models. Phytopathology, St. Paul, v. 103, n. 09, p. 906-919, 2013.

28. Silva, G. B.; Prabhu, A. S. Quantificação de conídios de Pyricularia grisea no plantio direto e convencional de arroz de terras altas. Fitopatologia Brasileira, Brasília, v. 30, n. 06, p. 569-573, 2005.

29. Urashima, A. S.; Leite, S. F.; Galbieri, R. Eficiência da disseminação aérea em Pyricularia grisea. Summa Phytopathologica, Botucatu, v. 33, n. 3. p. 275-279, 2007.

30. Verzignassi, C. D. F.; Lédo, F. J. S.; Batista, M. V.; Queiroz, C. A.; Corado, H. S.; Poltronieri, L. S.; Monteiro, L. C.; Silva, J. I.; Benteo, G. L.; Machado, J. C. Pyricularia grisea causando manchas foliares na cultivar BRS Capileto de capim-elefante (Pennisetum purpureum Schumach.) X milheto (Pennisetum glaucum (L.) R. Br.). Summa Phytopathologica, Botucatu, v. 39, n. 02, p. 140-141, 2013.

31. Villari, C.; Mahaffee, W. F.; Mitchell, T. K.; Pedley, K. F.; Pieck, M. L.; Hand, F. P. Early detection of airborne inoculum of Magnaporthe oryzae in turfgrass fields using a quantitative LAMP assay. Plant Disease, St. Paul, v. 101, n. 1, p. 170-177, 2017. 